\title{
Violated Copyright Protection in the Russian Federation
}

\author{
Roza losifovna Sitdikova
}

Ruslan Borisovich Sitdikov

\author{
Kazan (Volga region) Federal University, 18 Kremlyovskaya St., Kazan 420008, Republic of Tatarstan, Russian Federation
}

\section{Doi:10.5901/mjss.2014.v5n24p471}

\begin{abstract}
Abstarct
The article analyzes international and Russian law statutes and court practice about legal protection of copyright. The main legacy problems of copyright protection including modern approaches are noted. The main types of types of violations in practice and forms of protection are shown. The article also deal with problems of application of the copyright law based on the analysis of judicial practice of the state arbitration courts of the Russian Federation. Compensation in money terms is specially attended. There is a conclusion about the need for balance between private and public interests in copyright protection.
\end{abstract}

Keywords: Copyright infringement, legal measures of copyright protection, Russian Federation, private and public interests.

\section{Introduction}

It is well known that any system of legal protection will not be sufficiently effective without the ability to protect the violated rights. One of the experts in this field Peter Maggs Professor of the University of Illinois argues that «in the twenty-first century the accent will shift from drawing international treaties and national systems for the protection of intellectual property rights just on paper to the establishment of effective enforcement of the protection of intellectual property»[1]. This is also true with regard to the protection of copyright as a type of intellectual property rights [2]. There is the requirement of necessity that the state ensure effective protection measures in case of intellectual property rights infringement under the Trade-Related Aspects of Intellectual Property Rights (TRIPS) Agreement [3] and in other international treaties, such as Universal Copyright Convention [4] and World Intellectual Property Organization Copyright Treaty [5]. This is especially pertinent in connection with the entry of the Russian Federation into the World Trade Organization.

Article 5 (3) of the Berne Convention for the Protection of Literary and Artistic Works provides: "Protection in the country of origin is governed by domestic law" [6]. In accordance with the provisions of Articles 45 and 46 of the Constitution of the Russian Federation of December 12, 1993, each person is guaranteed by the state the legal protection of his rights and freedoms [7]. Today there is the possibility to assign civil, administrative and criminal responsibility in cases of copyright infringement in the Russian Federation. However, this paper will focus on the paths under civil law open to copyright protection. According to paragraph 1, Article 1248 of the Civil Code of the Russian Federation [8], disputes relating to the protection of the violated or disputed intellectual property rights are considered and resolved by the court.

The number of disputes in the field of the protection of intellectual property rights is constantly growing. According to the information provided on the website of the Supreme Arbitration Court of the Russian Federation, there were 2,996 cases related to intellectual property protection in 2011, while there were 5,069 cases in 2012. More than half of these cases involved copyright protection and related rights: 2,074 cases in 2011 and 2,192 cases in 2012 [9].

\section{Copyright Infringement Definition}

In Russian legal doctrine and practice copyright infringement is defined as any non-compliance with civil law in the use of objects of copyright. The range of copyright infringement is wide, encompassing the infringement of personal rights and the infringement of exclusive rights, which are distinguished depending on the type of violation of copyright.

Infringement of personal rights can be the violation of the integrity of the work, such as making changes to it, the assignment of authorship, the non-specificity or distortion of the author's or co-author's name when using the work, the promulgation of a work without the permission of the author, etc. 
Infringement of exclusive rights is the illegal use of the work, that is, actions done without the permission of the author or copyright holder, which according to Article 1270 of the Civil Code is part of the content of the exclusive rights. These actions include copying (replaying, including in electronic form), distributing, translating, publicly performing or displaying, and publishing works on the Internet [8]. In judicial practice, the majority of cases (94\%) are associated with the illegal manufacture and distribution of copies of works, that is, copies of the material objects, without permission. Such exemplars are called "counterfeit." At the same time, in Russia, as in other countries, the copying and distribution of works on the Internet is a widespread type of violation in practice. However, such cases refer to a rare species in Russian courts because of the difficulty in proving the violation and in the imperfection of the legislation in this area.

\section{Who can Apply to the Court for Protection}

Who can apply to the court for protection against copyright infringement? Obviously, this issue is of great practical importance.

First of all, an author can go to court if he did not transfer the exclusive rights to his work to anyone. When an author goes to court he is not required to prove right of authorship, because according to the Russian legislation, if there is no evidence to the contrary, then the person named on the original or copy of the work is recognized as the author. Also, in the Russian Federation copyright arises from the fact of creation and does not need state registration for its exercise. This provision is applicable also for all foreign authors who are nationals of states that are contracting parties to the Berne Convention for the Protection of Literary and Artistic Works. In accordance with Article 15 of the Convention, for the author of protected works: "In order that the author of a literary or artistic work protected by this Convention shall, in the absence of proof to the contrary, be regarded as such, and consequently be entitled to institute infringement proceedings in the countries of the Union, it shall be sufficient for his name to appear on the work in the usual manner."

A right holder who is not the author of a creative work must turn to the court to prove his exclusive ownership of the copyright. For example, he must produce an agreement on the transfer of his exclusive right. And it is important that the agreement transferred the exclusive right in full, with a right to protection; as a rule this is a 'contract for the alienation of the exclusive right' in a work (Art. 1285, Civil Code). (Prior to January 1, 2008, an exclusive right could be transferred by the publisher's (author's) agreement, which was often presented by plaintiffs in the court to confirm copyright ownership. In this case, the court had to analyze the agreement and interpret its content in order to determine the fact of the transfer of the exclusive right.) In accordance with Article 1254 of the Civil Code, the licensee can defend his rights under the exclusive license if the violation of the exclusive rights by others affects his rights.

Foreign authors and right holders have the right to appeal to the courts for protection of their rights, if provided by international treaties on copyright ratified by the Russian Federation. The Russian Federation is a party to the principal universal conventions on copyright, including the Berne Convention for the Protection of Literary and Artistic Works. There are many examples of the successful exercise of the protection of the rights of foreign right holders in the territory of the Russian Federation, the most famous involving MICROSOFT. In accordance with Article 5 of the Berne Convention and Article 1256 of the Civil Code, the legal protection regime extends to works whose authors are citizens of countries of the Union and states signatory to international treaties of the Russian Federation - in the MICROSOFT case, the United States - as well as to works of Russian authors.

\section{Legal Measures of Protection}

In case of copyright infringement legal measures of protection are applied. According to Article 1250 of the Civil Code, intellectual property rights are protected by the means provided by the Code with an allowance for the substance of the violated rights and the consequences of the violation of these rights. Specific ways to protect the violated exclusive rights are provided by Article 1252 of the Code. According to this latter article, exclusive rights to the results of intellectual activity and to means of individualization can be protected, in particular, by putting forth a claim:

- for declaration of the right,

- for restraint of acts that infringe or threaten to infringe,

- for damages,

- for seizure of material objects - against the manufacturer, importer, keeper, carrier, seller, other distributor, or bad-faith purchaser,

- for publication of the court decision on the violation and indication of the true right holder. 


\section{Declaration of the Right}

Declaration of the right as the way of protection is applicable where the copyright on the work of the person is attacked, denied or where there is a threat of such action. This requirement in practice implies both a recognition of copyright in general and the presence of the specific copyright of the person.

\section{The Requirement for Restraint of Infringement}

The requirement for restraint of infringement is used in practice in dispute resolution and may be a prohibition on the reproduction and distribution of pirated copies, a prohibition on the public display of works through the prohibition of advertising, offers for sale of copies, etc. One of the innovations of Part IV of the Civil Code is the direct indication in the statute of the possibility of the request for seizure of material objects against the manufacturer and others (listed above). These means of protection as well as the declaration of the right may be used separately or in combination with other means, e.g., the request for damages.

\section{Request for Damages}

Request for damages is that type of protection where the victim's property interest is satisfied by compensation to the victim for losses. It is a particular feature of copyright relations that when a copyright infringement causes little actual damage, losses can be expressed in the profits that the right holder could have expected to gain from the selling of his protected property. Justification for the size of damages, including lost profits, and a causal connection with the violation of his property rights are the responsibility of the victim, and this is often problematic. In this connection, Russian law has a special measure for redressing the possible property damage of the violation of exclusive rights. In accordance with paragraph 3, Article 1252 of the Civil Code, in case of infringement of the exclusive right the right holder shall have the right, instead of compensation for damages, to demand from the infringer payment of compensation for the infringement of the aforesaid right. In accordance with the provisions of Article 1301 of the Code, the amount of compensation which the right holder may require from the infringer can be determined in two ways: in the amount from 10,000 rubles to 5 million rubles determined at the discretion of the court; in double the amount of the value of the copies of the work or two times the amount of the value of the right to the use of the work determined according to the price which in comparable circumstances is customary for the lawful use of the work. The law gives to the right holder the right to choose the method of determining compensation. At the same time, in accordance with paragraph 3, Article 1252 of the Code, the right holder is exempt from proving damages caused to him. The right holder may require the infringer pay compensation for each case of improper use of the work or for the violation as a whole. The final amount of compensation to be recovered in accordance with section 3, Article 1252 of the Code shall be determined by the court and set within the limits established by law depending upon the nature of the infringement and other circumstances, taking into account the requirements of reasonableness and justice.

The circumstances that should be taken into account when determining the amount of compensation particularly include:

- the nature of the violation,

- the period of illegal use of the result of intellectual activity,

- the degree of guilt,

- the person's previous violations of the exclusive rights of the copyright owner,

- the right holder's probable losses.

While it is necessary to comply with the principles of reasonableness and good faith, the proportionality of the compensation to the consequences of the violation is also accented. Currently in judicial practice the use of such measures as the recovery of compensation is widespread. But in some cases the definition of a fair and reasonable amount of compensation is difficult because the legislator has established a minimum amount of compensation for each case of violation. The courts differently understand the notion of "each case of violation."

Thus, the Federal Arbitration Court of the Volga Region in judgment of 21.07.2009 of case number A6510975/2008 indicated that the author had the right to require "compensation for each of the five counterfeit copies of musical works recorded on CDs and sold. The amount of compensation may not be less than 10,000 rubles for each work." [10] Here, the Court found a copy of each work to be a single violation of the exclusive rights. At the same time, there are solutions where the court finds the single violation in the fact of the selling of one disc, regardless of the number 
of works. For example, in case number A56-16684/2007 the Arbitration Court of St. Petersburg and the Leningrad Region reduced the amount of compensation to the minimum and justified this by the fact that the defendant had sold only one disc, although the disc contained recordings of several works.

However, the tendency to seek to recover 10,000 rubles of compensation for each work on a single disc still prevails. That is, if the disc contains five songs, the minimum compensation will be 50,000 rubles, if 10 songs, 100,000 rubles, etc. According to this logic, in a case involving the selling of, for example, one copy of a book of poems, compensation of 10,000 rubles for each poem should be recovered. On the one hand, indeed, the sale of a counterfeit disc is a violation of the rights of all right holders whose works are recorded on the disc. On the other hand, is the recovery of 150,000-200,000 rubles of compensation proportionate to the offense where only one disc is sold and for a small amount, on average 100 rubles, and considering that the average price of a licensed disc is $300-500$ rubles for all the work regardless of the number of works that it contains. The discrepancy between violation and responsibility can upset the balance of private and public interests, the importance of which is emphasized by many experts [11].

Under these conditions, it is the court that must objectively and comprehensively evaluate all the circumstances of the particular case and give the legal and fair decision. Unfortunately, the current version of section 3, Article 1252 and Articles 1301 and 1311 of the Civil Code limit the courts substantially. Legal rules laid down in these articles do not always allow the courts to adjudicate in accordance with the principles of reasonableness and fairness. Obviously, in one case 50,000 rubles can be a significant sum for the sole proprietor, and in another case, for example, in the event of the persistent nature of the offense, 300,000 rubles will be adequate compensation for the consequences of the offense. It is good that the new edition Part IV of the Civil Code which comes into force in 01.10.2014 provides for measures aimed to the partial solving of this problem. In addition, the solution to this problem is impossible without achieving a fair balance between private and public interests in copyright. The court's decision in a particular case must be evaluated from this standpoint which presupposes compensation that is adequate and commensurate with the violation of the right holder's interests [12].

The infringer is a specific person who has infringed the intellectual property rights. In this case, civil proceedings may be instituted against the infringer regardless of the purpose of the violation of intellectual property rights and of the receipt by the infringer of any benefit from it. Different from other countries, vicarious liability is not widespread for copyright infringement in Russia. This is a defect of the Russian legislation and does not allow the court to resolve the case fairly. The courts do not examine the question of who has received benefits from the violation, and establish only the fact of the violation and who did it. It is sufficient to recover compensation from the infringer. It is important that the infringer made a profit for the infliction of an administrative penalty.

\section{Seizure of Material Objects}

Counteractions to the introduction and use of counterfeit copies of works is one of the tasks of copyright law and an obligation of the Russian Federation under international treaties. Paragraph 4, Article 1252 of the Civil Code is directed to the performance of this task. According to this article, counterfeit copies shall be removed from circulation and destroyed without any compensation whatsoever unless other consequences are provided by the law. The equipment and materials used for copyright infringement also may be seized.

\section{Publication of the Court Decision}

The existing legislation also provides other measures to protect violated rights of authors and other right holders. So, for example, it is possible to claim for publication of the judgment in the media. In case of violation of moral rights under Article 1251 of the Civil Code, compensation for moral damages under the rules established in Article 151 of the Code are applicable.

\section{Other Measures to Protect Violated Rights}

A novelty in the area of copyright protection is the introduction of Article 1253 of the Civil Code which provides for the liquidation of the legal entity and the termination of the activities of the individual entrepreneur that seriously and repeatedly violate exclusive rights. 


\section{Technological Protection of Copyright}

There are also specific copyright protection measures in the Civil Code: technological protection of copyright. In accordance with Article 1299 of the Code, any technology, technical devices or their components controlling access to a work, preventing or limiting the conduct of actions that are not permitted by the author or other right owner with respect to the work shall be recognized as technical means of protection of copyright. Illegal users, so-called "hackers," routinely attempt to circumvent or "crack" technical or security software. Experts in the field of software appreciate the scope of the problem of the hacking of computer programs and databases, especially with regard to banking and other confidential information. The activities of hackers in some cases pose threats to national security. With the advancements in digital technology the problem of the legal regulation of these developments is very serious.

From the civil law point of view, the use of technological protection measures is one of the means of self-defense (Art. 12, Civil Code). According to legal doctrine, self-defense is the action that a person takes independently in order to protect his rights in the event of danger of infringement, but the exercise of self-defense rights should only be directed at preventing a possible violation, and not at causing harm. If you have works on the Internet, in the Russian reality what seems to be effective is a combination of legal arrangements with the technical means of protection. When we want to protect our property, we hang a lock on the door, for we do not expect that everyone will obediently comply with the law.

The legal regulation of the use of technological protection measures can be divided into two aspects:

- on the one hand, the (first) problem of legitimacy and limits for the use of technical means of self-defense,

- on the other hand, the (second) problem of responsibility for attacks on the technical means of self-defense (circumvention of technological measures of protection), including cases of legitimate circumvention tools.

As shown above the second problem was partially solved by the legislation of the Russian Federation. But the legislation in this area needs to be improved. Because under the current edition of Article 1299 of the Civil Code the violation includes acts of circumvention of technical means, committed with legal purposes. Also, not always will circumvention of technological measures lead directly to a breach of copyright, so-called "break-in" protection can be committed with the purpose to copy them, and with the purpose of watching. Furthermore, copying can also have a different purpose, for example, the purpose to profit, or not. All of these factors must be taken into account in the application of sanctions for the circumvention of technological measures.

\section{Conclusion}

As we can see, the civil legislation of the Russian Federation provides enough opportunities for copyright protection, and it generally contributes to enhancing the legal protection of copyright. Judicial practice in civil cases on the protection of the rights of authors shows that if the claim is reasonable, the right holder can win the case. However, the authors and right holders should exercise their rights in good faith and in a reasonable way and apply legal measures only to restore their rights, and not for punishment. This helps to achieve a fair balance between private and public interests in copyright. To punish violators, both criminal and administrative measures can be applied. The author of this paper intends to write about this in subsequent publications.

\section{References}

Maggs PB Sergeev AP. Intellectual Property. - M.: Lawyer. 2000. Pp. 394.

Chisum D.S. Understanding Intellectual Property Law / Donald S. Chisum, Michael A. Jacobs. - Mattnef Bender\& CO., InC, 1992. - p. 128.

Agreement on Trade-Related Aspects of Intellectual Property Rights. Date Views 21.07.2014. http://www.wto.org/english/tratop_e /trips_e/t_agm0_e.htm

Universal Copyright Convention, with Appendix Declaration relating to Articles XVII and Resolution concerning Article XI 1952. Date Views 21.07.2014. http://portal.unesco.org/en/ev.php-URL_ID=15381\&URL_DO=DO_TOPIC\&URL_SECTION=201.html

WIPO Copyright Treaty (adopted in Geneva on December 20, 1996). Date Views ${ }^{-}$21.07.2014. http://www.wipo.int/treaties/en/ text.jsp?file_id=295166

Berne Convention for the Protection of Literary and Artistic Works of September 9, 1886, as revised at Paris on July 24, 1971, and amended on September 28, 1979. Date Views 21.07.2014. http://www.wipo.int/treaties/en/text.jsp?file_id=283698

The Constitution of the Russian Federation of December 12, 1993 // Russian Newspaper. - 1993. - Dec 25.

Collected Legislation of the Russian Federation. - 1994. - № 32. - St. 3301; 1996. - № 5. - St. 410; 2001. - № 49. - St. 4552; 2006. - № 52 (Part 1). - St. 5496.

The results of the arbitration courts of the Russian Federation. Date Views 20.07.2014. Date Views 21.07.2014. http://www.arbitr.ru/_ 
upimg/F6725D76252C4A924F859F4392196DD8_14.pdf

The judgment of the Federal Arbitration Court of the Volga Region at 21.07.2009 of case number A65-10975/2008.

Date Views 20.07.2014 http://kad.arbitr.ru/PdfDocument/c9832991-af87-4afc-91cf-197062459328/A65-10975-2008_20090721_ Postanovlenie\%20kassacii.pdf.

Gullian D. Copyright and the Public Interest / D. Gullian // II Studies. - 1994. - Vol. 14. - VCH. Verlagsgesellschaft MbH. - P. 1-8. Date Views 21.07.2014. http://cadair.aber.ac.uk/dspace/bitstream/handle/2160/1933/Davies\%20phd.pdf?sequence=1

Sitdikova RI "Determination of the amount of compensation in disputes concerning the infringement of copyright and related rights // IP. Copyright and related rights. 2009. № 11. Pp. 40-49. 